\title{
Effect of Whole Pituitary Extract on the Corpuscles of Stannius in Notopterus notopterus (Pallas)
}

By

\author{
Usha NARWARIYA and O.P. GUPTA* \\ Department of Zoology \\ Dr. H.S. Gour Vishwavidyalaya \\ SAGAR (M.P.) 470 003, INDIA.
}

- Received for Publication, October 9, 1988-

\begin{abstract}
Key words: Calcium metabolism, Corpuscles of stannius, Pituitary
Summary: Administration of pituitary extract brings important change in the cells of the corpuscles of stannius. Two variety of cells are found in the corpuscles of stannius of control group, one with dense cytoplasm while the other possess nonreactive cytoplasm. Under the influence of whole pituitary extract, there is an intense cell activity in corpuscles of stannius suggesting more synthesis of hypocalcemic factor. Other possible reasons like stimulation of interrenal, thereby activating corpuscles of stannius have also been discussed. The possible involvement of ACTH or cortisol and synergistic effect of prolactin in promotion of hypercalcemia have also been suggested.
\end{abstract}

The work on the effect of whole pituitary extract on corpuscles of stannius in teleost fish is scanty, while the involvement of pituitary gland in calcium metabolism of fish has long been suspected (Fontaine, 1956; Nussbaum, 1965; Stanley and Fleming, 1967; Olivereau and Charlier, Baradue, 1965; Chan et al., 1968; Ogawa, 1968). Recently Pang (1986) has published an interesting account on the hormonal control of calcium metabolism.

It was suggested by some workers that the regulation of this electrolyte in euryhaline fish is under the control of hypocalcemic activity of the corrpuscles of stannius and hypercalcemic properties of pituitary gland (Pang, 1971a, b, c, 1972; Pang et al., 1973a). The pituitary contains active prolactin cells. The role of rostral pars distalis containing prolactin secreting cells in regulation of calcium metabolism has also been confirmed by few workers (Stanley and Fleming, 1967; Chan and Chesterjones, 1968; Pange, 1971; Pang et al., $1973 \mathrm{~b}, \mathrm{c})$. Corpuscles of stannius are reported to be involved in calcium metabolism and as such their histological response to the whole pituitary extract needs further investigations. Some workers (Thakur et al., 1974; Verma, 1977) have confirmed that the administration of whole pituitary extract brings important changes in adrenocortical cells in Nandus nandus and also in adrenal tissue in Mystus vittatus (Hora, 1981).

*Offprint request to O.P. Gupta

\section{Materials and Methods}

The fish, Notopterus notopterus (Pallas) were collected from local Sagar lake, Sagar, M.P., India. About three hundred animals were collected for this experiment in the month of February, 1987 since female animals have to be identified and separated in different aquaria. They were kept in aquarium and acclimatised for one week prior to starting the experiments. They were also not fed throughout the experiment. Healthy fish ranging from 11 to $15 \mathrm{~cm}$ in length were selected to act as control and for experimentation as well.

\section{Experimental Procedure}

\section{Preparation of Whole Pituitary Injection:}

The whole pituitary extract was prepared from the female fish collected during post-spawning period, i.e. in the month of February. Dissection was performed under the binocular microscope and pituitary gland was taken out and homogenate in $0.5 \mathrm{ml}$ of fish saline $(0.6 \%)$. The centrifugation was done for 5 minutes at 4000 r.p.m. and supernatant was collected. This quantity was found suitable for one injection after many trials with different quantities of saline.

The injections were given only to the female fish belonging to the same lot at intervals of 12 hours. In all 4 injections were given and the concerned tissue was fixed on third day, 54 hours after the first injection. All injections were given intra-muscularly near the base 
of the caudal fin. Control was also kept throughout the experiment. The fish were killed by a single blow on the head and tissue was immediately fixed in the following fixatives: Alcoholic Bouin (24 hr), Bouin Holland ( $24 \mathrm{hr}$ ), Helly's fluid ( $24 \mathrm{hr}$ ) and Carnoy's fluid (1-3 hr).

The tissue was dehydrated and embedded in paraffin wax. Sections were cut at $6 \mathrm{um}$ and stained with Hematoxylin Eosin, Masson's Trichome (Masson, 1929), Mallory's Triple (Gurr, 1962) and Heidenhain's Azan (Gurr, 1962) stains.

The cellular and nuclear diameter were measured with the help of an ocular micrometer disc (Japan).

\section{Morphometric Procedure:}

Both experimental and control tissue were treated similarly and stained sections were prepared at $6 \mathrm{um}$ to study the hypertrophy of cells and their nuclei. Sections used for counting the cells were stained with hematoxylin-eosin. The cells and nuclei were then counted to get the exact number of cells in a particular corpuscles of stannius. The total area of cells and nuclei in a particular corpuscles of stannius were measured by with the help of an ocular micrometer disc (Japan). The mean area for one cell and nucleus was calculated. Observations were made randomly from different sections or slides in both from experimental and control tissue.

All statistics presented in this paper are means \pm standard errors. Students ' $t$ ' test was made use of, for testing the significance of difference between the means of readings of experimental and control groups in this study, using $5 \%$ level of significance.

\section{Results}

The corpuscles of stannius are light pale cream and oval bodies lying embedded on the anterior most part of the mesonephros. Between one or two (in exceptional cases) are present. Each measures between 4 to $5 \mathrm{~mm}$ long and about $2 \mathrm{~mm}$ in diameter. Corpuscles of stannius are covered by a thin layer of connective tissue. The connective tissue sheath divides the glands into lobules. This structure is richly supplied by thin walled blood vessels.

The group of pituitary injected fish are found dull in movement with disturbed equilibrium and its swimming is restricted at the bottom of aquaria. The colour of fish is also affected and its changes from greenish black to yellowish black, while saline injected fish are very agile and found moving freely upward and downward. The colour of fish is retained to its original greenish black. There was no apparent changes in the general appearance of corpuscles of stannius but the colour of the corpuscles of stannius is also affected by the injection of the whole pituitary extract.

By the light microscopic study of saline injected fish, the size of corpuscles of stannius remains normal. They are light cream in colour and oval in shape, the lobes of corpuscles of stannius are clear with interlobular spaces (Fig. 3). The cells are big with oblong nuclei and possess hyaline cytoplasm (Fig. 4). Central canal is clear. Vascularization is normal. There seems to be two types of cells as regarding their staining properties is concerned - type one consists dense cytoplasm while the second contains non-reactive cytoplasm. However, this point requires further confirmation by electron microscopy.

The whole pituitary injected corpuscles of stannius are observed as small in size. The shae of corpuscles of stannius varies from oval to elongated with clear but compact lobes (Fig. 5). Cells enlarged than control group while the central canal is not visible. The nuclei become oval and highly granular (Fig. 6). Nucleoli are not visible. Vascularization is high when compared with control group.

\section{Observations}

\section{Effect on the Diameter of Cells in Corpuscles of Stannius (Table 1, Fig. 1)}

The mean area for 30 cells in control group comes to $4.3 \pm .17 \mathrm{um}$ while the mean area for experimental 30 cells is $5.20 \pm .09$ um.

\section{Effect on Nuclear Size of Corpuscles of Stannius} (Table 1, Fig. 2).

The mean area of control is $2.1 \pm 0.3$ um while it is $2.3 \pm 0.81$ um for experimental group.

\section{Discussion}

The results of this experiment support the hypothesis that a close connection between pituitary and the corpuscles of stannius do exists. A number of workers (Pang, 1971a, b, c, 1972) have tried to find out the relationship between the pituitary and calcium metabolism. This is an unequivocal contention that the pituitary is hypercalcemic in nature. It contains a specific hypercalcemic factor. Prolactin and calcitonin are also detected in hypophysis (Deftos et al., 1980). Fontaine (1956) was the first to suggest that pituitary of fish produce a hypercalcemic factor, which, he observed in freshwater hypophysectomized cells. Hypocalcemic can be corrected by either whole pituitary homogenate or the homogenates of the portion of pituitary which contains the largest proportion of the prolactin cells (Pang, Schreibman and Griffith, 1973).

Administration of pituitary gland extract causes hypercalcemia in female eels that is related to ovarian 


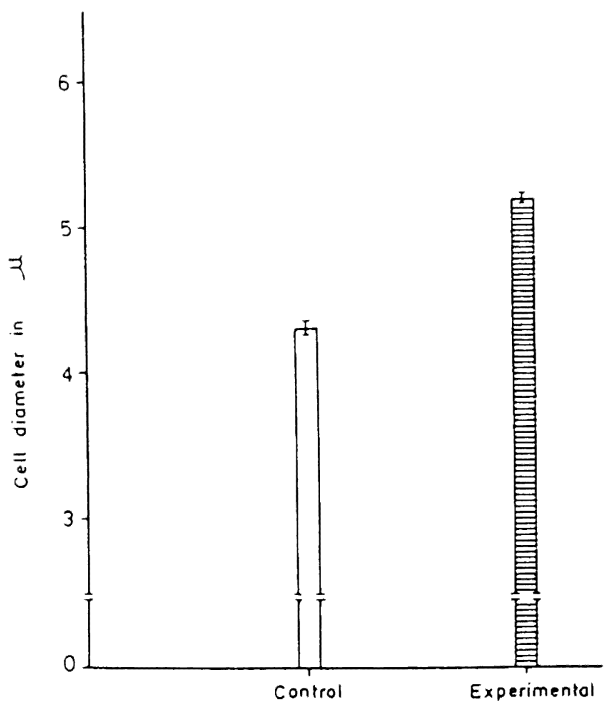

Fig. 1. Effect of whole pituitary extract on the diameter of cells of corpuscles of stannius.

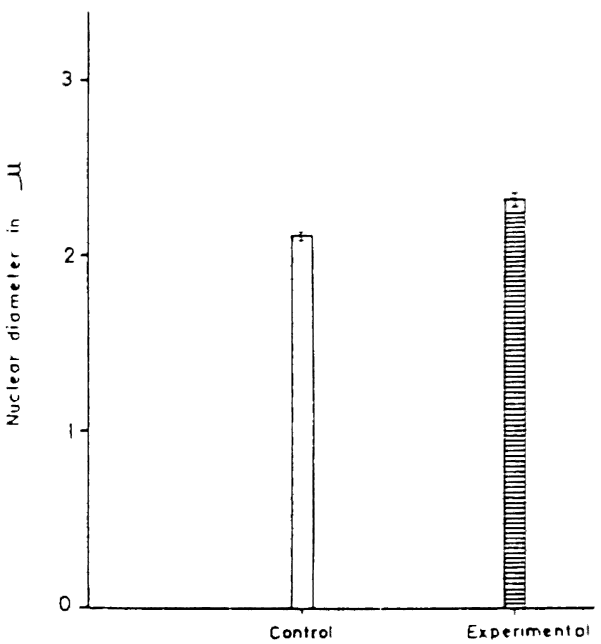

Fig. 2. Effect of whole pituitary extract on the diameter of nuclei of corpuscles of stannius.

Table 1. Statistical Parameters of the Control and Experimental Corpuscles of Stannius

\begin{tabular}{|c|c|c|c|c|c|c|c|}
\hline & & Mean & $\begin{array}{l}\text { Differences } \\
\text { of the two } \\
\text { Means }\end{array}$ & $\begin{array}{l}\text { Standard } \\
\text { Deviation } \\
\text { \& Standard } \\
\text { Error }\end{array}$ & $\begin{array}{c}\text { Calculated } \\
\mathrm{t} \\
\text { Value }\end{array}$ & $\begin{array}{l}\text { Signi } \\
\text { ficance }\end{array}$ & $\begin{array}{c}\text { Increased } \\
\text { OR } \\
\text { Decrease }\end{array}$ \\
\hline Cellular Area & $\begin{array}{l}\text { Control } \\
\text { Experi- } \\
\text { mental }\end{array}$ & $\begin{array}{l}4.3 \mathrm{u} \\
5.2 \mathrm{u}\end{array}$ & $.9 \mathrm{u}$ & $\begin{array}{l}\mathrm{SD}=.984 \\
\mathrm{SE}=.179 \\
\mathrm{SD}=.505 \\
\mathrm{SE}=.092\end{array}$ & 4.378 & $\begin{array}{l}\text { Highly } \\
\text { Signi- } \\
\text { ficant }\end{array}$ & Increase \\
\hline Nuclear Area & $\begin{array}{l}\text { Control } \\
\text { Experi- } \\
\text { mental }\end{array}$ & $2.1 \mathrm{u}$ & $.2 \mathrm{u}$ & $\begin{array}{l}\mathrm{SD}=.191 \\
\mathrm{SE}=.034 \\
\mathrm{SD}=.444 \\
\mathrm{SE}=.081\end{array}$ & 2.226 & $\begin{array}{l}\text { Weak } \\
\text { Signi- } \\
\text { ficant }\end{array}$ & Increase \\
\hline
\end{tabular}

Abbreviations: $\mathrm{SD}=$ Standard Deviation $\mathrm{SE}=$ Standard Error.

maturation (Fontaine et al., 1964). This can also explain the hypercalcemia observed in female fish during such period. In all the experimental animals, which are injected with whole pituitary extract, there is a clear hypertrophy in corpuscles of stannius, while the control group treated with the same quantity of the vehicle remains unaffected. The intensity of stimulation of corpuscles of stannius by the prolactin administration depends upon the presence of calcium in external medium (Olivereau, 1978). This work relates the experiments in freshwater, which contains low calcium concentration $1.5-2 \mathrm{mmol} /$ litre. The stimulatory effect is less evident here which is correlated to the endogenous release of prolactin and level of the resulting hyper- calcemia which was not possible to measure in our laboratory. However intense cell activity suggests that there is more synthesis of hypocalcemia factor (probably hypocalcin), due to an extra high dosage of the hypercalcemic hormone which was injected to the experimental group as whole pituitary extract. This is also evident from histological examination in Notopterus notopterus (Pallas), which shows a clear difference between control and experimental tissue in corpuscles of stannius. This difference also points out the increased activity in the corpuscles of stannius under the influence of whole pituitary extract.

Hypercalcemia (as total plasma calcium) was also induced in both immature and mature males and 


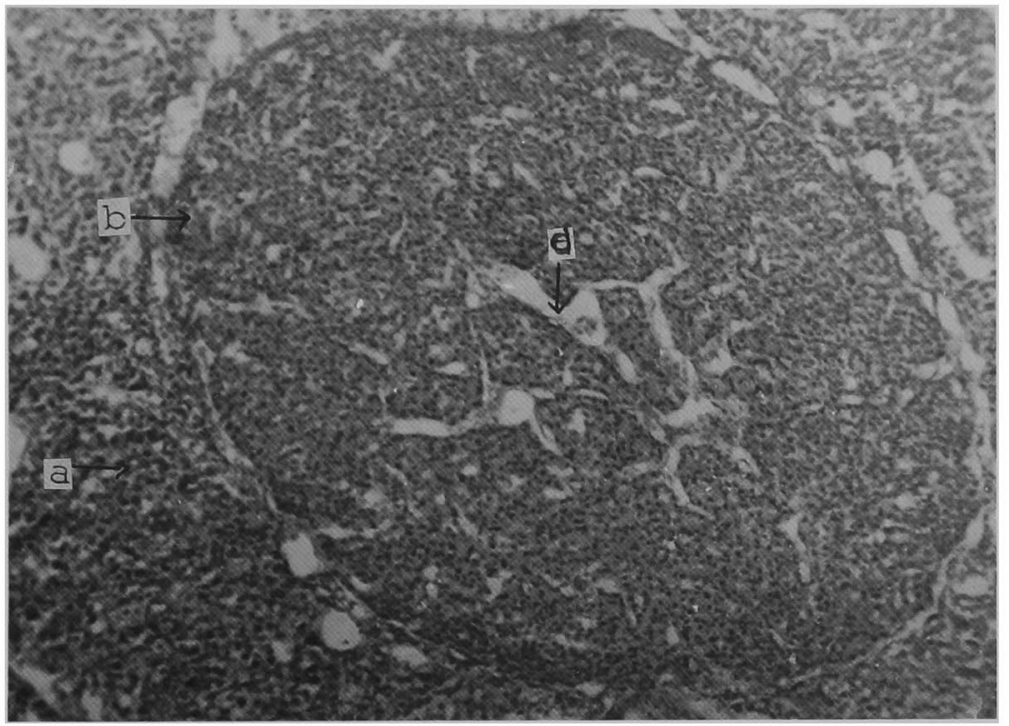

Fig. 3. Section of kidney showing normal and oval corpuscles of stannius. Lobes and interlobular spaces are clear. Hematoxylin-eosin stain $\times 150$.

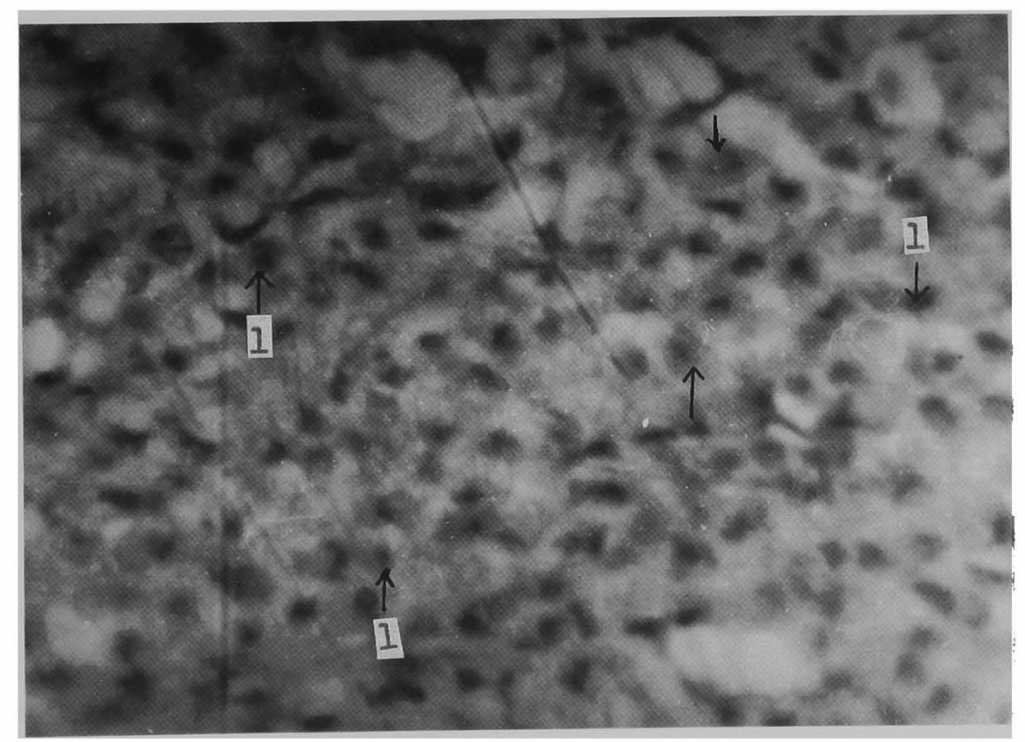

Fig. 4. Magnified views of Fig. 3 showing big cells (arrow) with variable nuclei, while the cytoplasm is hyaline. Hematoxylin-eosin stain $\times 900$.

females in Salmo gairdneri by estradiol injections (Bjornsson, 1981) and by injection of hypophysial extract (Peignoux-Deville et al., 1975; Yamauchi et al., 1978b) ins everal teleost species Anguilla anguilla. The collection for this work was made in the month of February when the fishes are in the state of postspawning period, thereby also developing a gradual hypercalcemia. The injection of whole pituitary extract alongwith the intact hypophysis thus may affect plasma calcium level by inducing hypercalcemia through gonadotropin induced ovarian estradial secretion (Bjornsson and Haux, 1985). This hypercalcemia in plasma should lower down to a optimum levels, for which corpuscles of stannius become active and show high degree of activity as observed in whole pituitary extract injected animals. However the role of stimulated interrenal by pituitary in secretion of more crotisol at this step and thereby stimulating corpuscles of stannius to secrete more hypocalcemic factor can also not be ruled out and requires further investigation.

Female fish possess higher serum calcium level during sexual maturation which is a known fact and the reason being that hypophysial gonadotrophins induced estradiol secretion by the ovaries (Sundararaj, 1981). This increase ia also associated with a rise in protein bound calcium and not in ionic calcium (Bailey, 


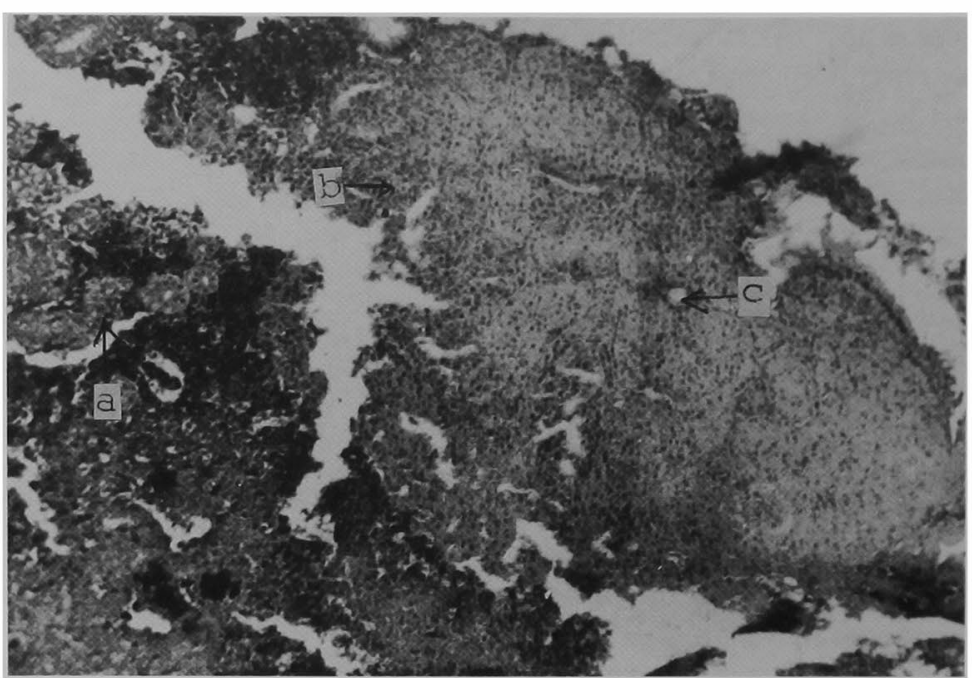

Fig. 5. Section of kidney showing small and elongated corpuscles of stannius with compact lobes.

Hematoxylin-eosin stain $\times 150$.

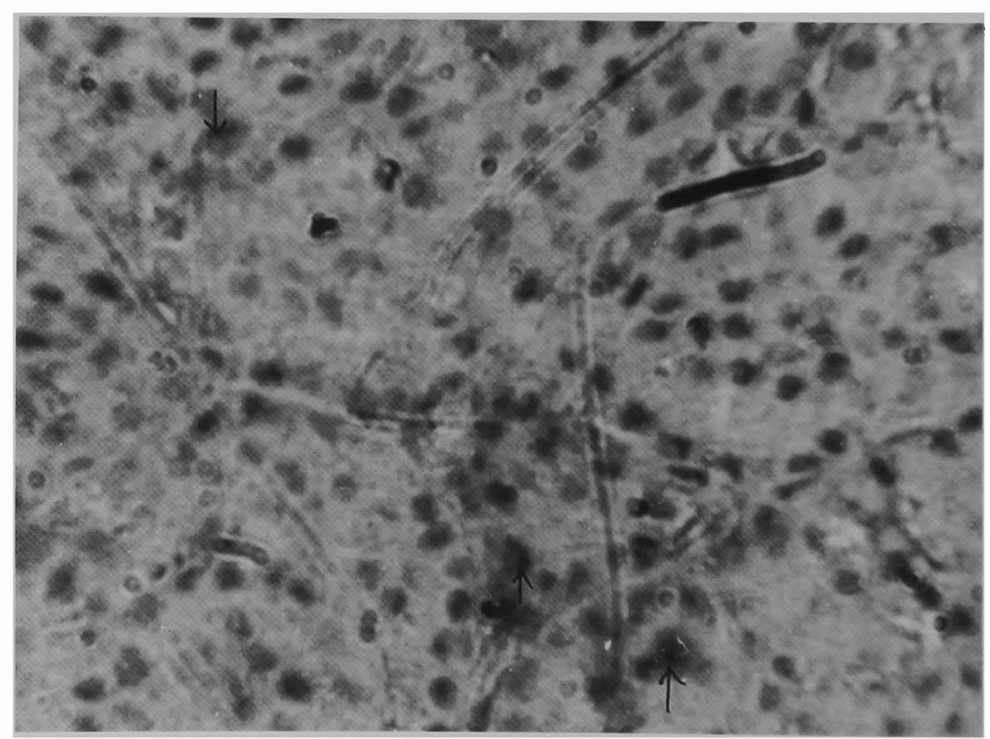

Fig. 6. Magnified view of Fig. 5 showing oval nuclei which are deeply stained (arrow)

Hematoxylin-eosin stain $\times 900$.
Abbreviations
a: Kidney
b: Corpuscles of stannius
c: Central canal
d: Interlobular space
e: Variable nuclei.

1957a; Urist and Schjeide, 1961; Chan and Chesterjones, 1968). By providing an extra amount of exogenous hypercalcemic factor in the form of whole pituitary extract, it is tried to correct the serum calcium level and it is suggested that corpuscles of stannius should lower it, in whole pituitary extract injected animals. This is evident by the higher degree of activity of corpuscles of stannius in experimental group.

Agreeing to the view of previous workers (Pang et al., 1973) that ACTH or cortisol (secreted by interrenal in response to ACTH stimulation) and prolactin may have a synergistic effect in the promotion of hyper- 
calcemia in the fish kept in low calcium environment and $\mathrm{ACTH}$ imitates the other hormones like MSH and vice-versa at higher dose levels, the whole pituitary extract is injected in the intact animals to note the calcium level in the experimental animals. This level seems to be corrected by the ACTH from the pituitary at high dosage level. ACTH is effective in correcting hypercalcemia by the stimulation of interrenal and which in turn finally stimulate corpuscles of stannius through the pituitary interrenal axis (Gupta et al., 1983; Prasada Rao and Subhedar, 1974).

The present investigation also supports the view of previous workers (Pang et al., 1973) that the pituitary gland has a hypercalcemic effect, which is evident in low calcium environment irrespective of the presence of other important electrolytes like sodium in the surrounding medium.

\section{Acknowledgements}

The authors are thankful to Prof. B.K. Srivastava, Head of the Zoology Department, Dr. H.S. Gour Vishwavidyalaya, Sagar, for providing lab and other facilities.

\section{References}

1) Bailey, R.E.: The effect of estradiol on serum calcium phosphorus and protein of goldfish. J. Expt. Zool., 136: 455-469, 1957a.

2) Bjornsson, B.T., C. Haux and T. Hansson:: Effect of hypophysectomy on the regulation of plasma levels of sodium and chloride in rainbow trout in fresh water. In exogenous and endogenous influences on metabolic and neural control. pp. 201-202, Pergamon Press, Oxford, 1981.

3) Bjornsson, B.T.: Calcium balance in teleost fish: Views on endocrine control. Ph.D. thesis. Dept. of Zoophysiology, University of Goteborg, Sweden, 1985.

4) Bjornsson, B.T. and Carl Haux: Distribution of calcium magnesium and inorganic phosphate in plasma of estradiol 17B treated rainbow trout. J. Comp. Physiol. B 155: 347-352, 1985.

5) Bonga, S.E.W. and G. Flik and J.C. Fenwick: Prolaction and calcium metabolism in fish: Effects on plasma calcium and high affinity $\mathrm{Ca}^{++}$ATPase in gills. Elsevier Science Publisher B.V. Endocrine control of bone and calcium metabolism, D.V. Cohn, J.T. Potts Jr. T. Fujita, editors, pp. 188-190, 1984.

6) Chan, D.K.O. and I. Chesterjones: Regulation and distribution of plasma calcium and inorganic phosphate in the European eel (Anguilla anguilla L.). J. Endocrinol., 42: 109-117, 1968.

7) Chan, D.K.O., I. Chesterjones, R.N. Smith: The effect of mammalian calcitonin on the plasma levels of calcium and inorganic phosphate in the European eel (Anguilla anguilla L.) Gen. Comp. Endo., 12: 243-254, 1968.

8) Deftos, L.J., D.W. Burton, W.B. Watkins and B.D. Catherwood: Immunohistological studies of artiodactyl and teleost pituitaries with antisera to calcitonin. Gen. Comp. Endo., 42: 9-18, 1980.

9) Fenwick, J.C. and Bonga, S.E.W.: Hormones and Osmoregulation: Endocrine involvement in calcium regulation in teleosts (In "Exogenous and endogenous influences on metabolic and neural control", by A.D.F. Addink and N. Spronk. pp. 339-350), 1982.

10) Fleming, W.R. and J.N. Ball: The effect of prolactin and ACTH on the sodium metabolism of Fundulus kansae held in deionized water, sodium enriched fresh water, and concentrated sea water. Z. Vergleich. Physiol., 76: 125-134, 1972.

11) Fontaine, M.: The hormonal control of water and salt electrolyte metabolism in fish. Mem. Soc. Endocr., 5: 69-81, 1956.

12) Fontaine, M.: Corpuscles de stannius et regulation ionique $(\mathrm{Ca}$, $\mathrm{K}, \mathrm{Na}$ ) du milieu interierur de l'anguille (Anguilla anguilla $\mathrm{L}$.). C.R. Acad. Sci. Paris, 259: 875-878, 1964.

13) Gray, P.: The microtomists formulary and guide, Blakiston Company, New York, 1953.

14) Gupta, O.P. and W. Hanke: The role of the pituitary-interrenal axis during osmotic stress in teleost fish. Zool. Jb. Physiol. 87: 79-91, 1983.

15) Gurr, E.: Method of Analytical Histology and Histochemistry, London, 1958.

16) Hora, S.K.: Histophysiological studies on the extra adrenal (Interrenal) location of the chromaffin tissue in the kidney, spleen and the ovary of the Siluraid fish, Mystus vittatus (Bloch). Ph.D. Thesis, University of Saugar, 1981.

17) Lillie, R.D.: Histopathologic Technic and Practical Histochemistry. Blakiston Company, New York, 1957.

18) Nussbaum, N.S.: The effects of hypophysectomy and thyroxin therapy on scale regeneration in goldfish, Carassius auratus Linn. Amer. Zool., 5, 234, 1965.

19) Ogawa, M.: Osmotic and ionic regulation in goldfish removal of the corpuscles of stannius or pituitary gland. Can. J. Zool., 46: $669-676,1968$.

20) Olivereau, $M$. and $M$. Chartier-Baraduc: Aldactone et osmoregulation chez l'Anguille. C.R. Herb. Scances Acad. Sci. Ser. D. Paris, 159: 1498-1503, 1965.

21) Olivereau, M. and J. Olivereau: Prolactin, hypercalcemia and corpuscles of stannius in sea water eels. Cell. Tiss. Res., 186: 81-96, 1978.

22) Pang, P.K.T., N.B. Clark and K.S. Thomson: Hypocalcemic activities in the ultimobranchial bodies of lung fishes, Neoceratodus forstezi and Lepidosiren paradoxa and teleosts, Fundulus heteroclitus and Gadus morhua. Gen. Comp. Endocr., 17: 582-585, 1971a.

23) Pang, P.K.T., R.W. Griffith and G.E. Pickford: Hypocalcemia and tetanic seizures in hypophysectomized killifish. Fundulus heteroclitus. Proc. Soc. Expt. Biol. Med., 136: 85-87, 1971 b.

24) Pang, P.K.T.: The relationship between corpuscles of stannius and serum electrolyte regulation in killifish. Fundulus heteroclitus. J. Exp. Zool., 178: 1-8, 1971c.

25) Pang, P.K.T.: Hormonal control of serum calcium levels in fish. Proc. Int. Congr. Endo. 4th, Inst. Congr. Ser. Excerpta Med. Found. No. 256, p. 182, 1972.

26) Pang, P.K.T.: Endocrine control of calcium metabolism in teleosts. Amer. Zool., 13: 775-792, 1973.

27) Pang, P.K.T., M.P. Schreibman and R.W. Griffith: Pituitary regulation of serum calcium levels in the killifish Fundulus heteroclitus L. Gen. Comp. Endo., 21: 536-542, 1973c.

28) Pang, P.K.T., M.P. Schreibman and R.W. Griffith: The pituitary gland and calcium metabolism in Fundulus diaphanus (Teleosterii). Gen. Comp. Endo., 20: 358-361, 1973b.

29) Pang, P.K.T., M.P. Schreibman and F. Balbotin and R.K. Pang: Prolactin and pituitary control of calcium regulation in the killifish, Fundulus heteroclitus. Gen. Comp. Endo., 36: 306-316, 1978.

30) Pang, P.K.T. and R.K. Pang: Hormones and calcium regulation in Fundulus heteroclitus, Amer. Zool., 26: 225-234, 1986.

31) Peignoux-Deville, J., E. Lopez, F. Lallier, E. Martelly and C. Milet: Responses of the ultimobranchial body in eels. (Anguilla 
anguilla L.) maintained in sea water and experimentally matured, to injections of synthetic salmon calcitonin. Cell. Tiss Res., 164: 73-83, 1975

32) Stanley, J.G. and W.R. Fleming: The effect of hypophysectomy on the electrolyte content of Fundulus kansae held in fresh water and in sea water. Comp. Biochem. Physiol., 21: 489-497, 1967.

33) Subheder, N. and P.D. Prasada Rao: Effects of some corticosteroids and metopirone on the corpuscles of stannius and interrenal gland of the catfish Heteropneust fossilis (Bloch). Gen. Comp. Endo., 23: 403-414, 1974.

34) Sundararaj, B.I.: Reproductive physiology of teleost fishes. FAO, ADCP Rep. 81, 16, 1981.
35) Thakur, D.P. and Srivastava, R.K.: Effect of whole pituitary extract on the adrenal tissue of fasting Nandus nandus. Zoologis. Jahorbuch. Anato. Leipzig, Vol. 90, 351-359, 1974.

36) Urist, M.R. and O.A. Schjeide: The position of calcium and protein in the blood of oviparous vertebrates during estrus. J. Gen. Physiol., 44: 743-756, 1961.

37) Verma, M. Madan: Ultra-structural evidence for aldosterone and corticosterone secreting cells in the adrenocortical tussue of the American Bulfrog Rana catesbeina. Gen. Comp. Endo., 33: 61-75, 1977.

38) Yamauchi, H., H. Orimo, K. Yamauchi and H. Takahashi: Increased calcitonin levels during ovarian development in the eel, Anguilla japonica. Gen. Comp. Endo., 36: 526-529, 1978 b. 